\title{
ARTICLE \\ Geochemical Trends in Weathering Profiles and Their Underlying Precambrian Basement Rocks in Akure, Southwestern Nigeria
}

\author{
Oluwatoyin O. Akinola Olusola A. Ola Olorun" \\ Department of Geology, Ekiti State University, Ado-Ekiti, Nigeria
}

\section{ARTICLE INFO}

Article history

Received: 2 June 2021

Accepted: 21 July 2021

Published Online: 10 August 2021

Keywords:

Akure

Nigeria

Geochemical trends

In-situ weathering profile

Kaolinitic

\begin{abstract}
Akure area in southwestern Nigeria falls within the basement complex underlain by migmatite, quartzite granite and charnockite. Geochemical features of these crystalline rocks and their overlying in-situ weathering profiles are investigated and reported. Analytical result from ICP-MS facility at the University of Malaya reveals average $\mathrm{SiO}_{2}$ content in quartzite $(91.1 \%)$, granite $(73.8 \%)$, migmatite $(67.4 \%)$ and charnockite $(58.6 \%)$ categorize the rocks as siliceous. $\mathrm{SiO}_{2}$ contents in the weathering profiles above these rocks are $61.9 \%, 60.2 \%, 52.2 \%$ and $54.6 \%$ respectively. Alumina contents in the weathering profiles overlying quartzite $(23.8 \%)$, granite $(19.9 \%)$, migmatite $(26.3 \%)$ and charnockite $(24.3 \%)$ are substantially higher than the precursor rocks. In the same order, average alkali $\left(\mathrm{Na}_{2} \mathrm{O}+\mathrm{K}_{2} \mathrm{O}\right)$ contents in the profiles are $3.38 \%, 3.42 \%$, $3.48 \%$ and $2.68 \%$. Chemical features of the profiles reflect that there exists some correlation between the chemistry of crystalline basement and their in-situ weathering profiles. The residual soils contain low plastic clays with kaolinitic characteristics and compare well with other clays reported from other parts of Nigeria basement complex.
\end{abstract}

land mass of Ondo State is covered by crystalline rocks and this occur towards the north. The general landscape of Akure area which consists of gently rolling hills of average heights has an undulating topographic outlook. Akure and its environs are underlain by basement complex rocks. A dominant part of these rocks is weathered in-situ to form profiles with varying thicknesses and physical properties over these residual hills. Chemical weathering which ultimately transforms these residues becomes so pronounced that they differ from their precursor basement rocks. In the current study, these weathering profiles are investigated for geochemical trends that may be related to their parent rocks.

The crystalline rocks in Akure area forms part of the Precambrian basement complex of southwestern Nigeria

*Corresponding Author:

Olusola A. Ola Olorun,

Department of Geology, Ekiti State University, Ado-Ekiti, Nigeria; Email: olusola.ola-olorun@eksu.edu.ng 
which on a regional continental scale is an extension of the Pan-African province that extends into over twelve countries in Africa. Within this province, the Nigeria domain contains crystalline and sedimentary rocks which share the landmass almost equally. The sedimentary rocks which are Cretaceous to Recent in age occupy the major basins and overly the basement complex with recognizable unconformities. The crystalline rocks are categorized into three petrological groups. These are migmatite gneiss quartzite complex, schist belts and granite (Figure 1). Previously, several authors e.g. ${ }^{[1-8]}$ have presented the petrological affiliations, mineralogical features, petrochemical characteristics and structural geology of these ancient basement in sections. While the petrogenetic synopsis and geochronology of the rock units have been investigated e.g. ${ }^{[9-13]}$. More frequently reported among these rocks is the Schist belts e.g. ${ }^{[14-17]}$ which host several tangible economic mineralization in gold ${ }^{[18,19]}$ Banded Iron Formation (BIF) ${ }^{[20-23]}$, marble, ${ }^{[24]}$ and several clay deposits scattered within the basement complex of southwestern Nigeria e.g. [25-27]. However, Akure section of the basement complex of southwestern Nigeria is underlain by migmatite-gneiss, quartzite, granitoids (undifferentiated coarse-grained granite $(\mathrm{OGu})$, medium-grained granite $(\mathrm{OGe})$, porphyritic biotite and biotite hornblende granite (OGp), fine-grained granite (OGf) and charnockitic meta-intrusive (Ch) (Geological Survey of Nigeria, ${ }^{[31]}$ ) (Figure 2). This geological map was adopted for the study and it guided immensely during geological sampling. About $70 \%$ of the study area is covered by migmatite which extends from north-western to north-eastern direction. However, the north central part of Akure is occupied by granite-charnockite units. Migmatite-gneiss had geological contacts with charnockite towards the west and coarse-porphyritic granite towards east and medium-grained granite toward northeast. The granite-chanockite association continues along a linear strip into Ekiti and Kwara State in the north. Field examination reveals dominance of quartzo-feldspartic aggregates which points the rocks as acidic. However, the opaque constituents are more obvious in charnockitic unit, granite only has specks of these minerals scattered among the interlocking aggregates with dominance of biotite and iron oxide which form the main mafic minerals. The relationship between textural characteristics, mineralogical composition, degree of weathering and strength of rocks has been established in several investigations ${ }^{[28,29]}$.

\section{Materials and Methods}

Field geology entails sampling of the chemically decayed in-situ rocks overlying bedrocks in the study area. Samples are collected at different locations and at different depths within each profile with the help of a hand trowel and are labelled accordingly. Samples of the soil profile are subjected to laboratory procedure first by drying for two weeks at room temperature; they are kneaded and subsequently pulverized. Rocks and weathering profiles powders are packaged in air-tight plastic containers and analysed by the ICP-MS facility at the Department of Chemistry, University of Malaya, Malaysia. Four samples each were collected from profile above the quartzite, charnockite, granite and migmatite. Another set of four samples each of the basement complex rocks represented by quartzite, charnockite, granite and migmatite were subjected to geochemical analysis. The total number of samples was limited to thirty-two (sixteen for weathering profiles and sixteen for fresh basement rocks). For analytical procedures, collected weathering profile and underlying basement rock samples were dried at $60^{\circ} \mathrm{C}$, crushed, pulverized and sieved to -80 mesh. About $0.2 \mathrm{~g}$ samples aliquot was weighed into a graphite crucible and mixed with $1.5 \mathrm{~g}$ of $\mathrm{LiBO}_{2} / \mathrm{LiB}_{4} \mathrm{O}_{7}$. The samples were heated in a muffle furnace which has its temperature set at $980^{\circ} \mathrm{C}$ for $30 \mathrm{mins}$. The cooled beads were dissolved in $100 \mathrm{~mL}$ of $5 \% \mathrm{HNO}_{3}$. The aliquot of the solution was poured into a propylene test tube. Calibration standards and verification standards are included in the sample sequence. Sample solutions are injected into an ICP-MS (Perkin- Elmer Elan 9000) and major elements composition was determined.

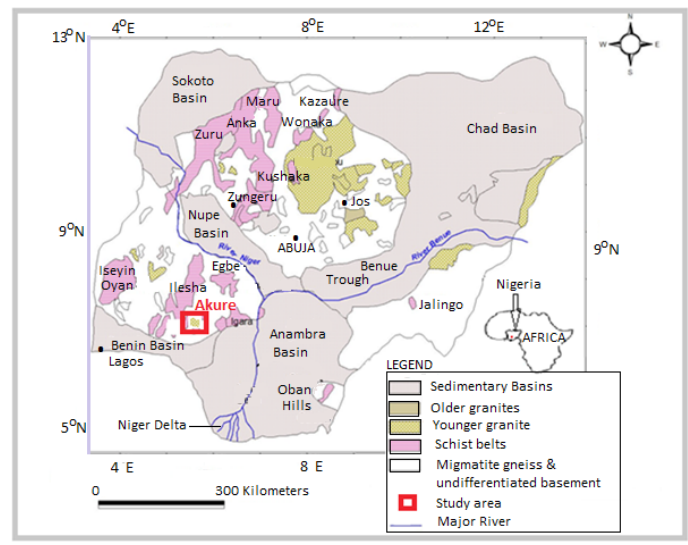

Figure 1. Geological map of Nigeria showing study area (after ${ }^{[30]}$ )

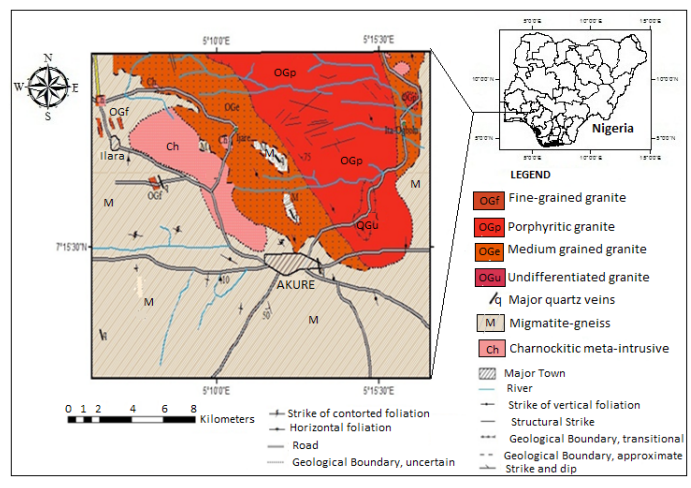

Figure 2. Geological map of the study area after GSN ${ }^{[31] .}$ 


\section{Results and Discussion}

\subsection{Description of the Profiles}

The profiles are associated with the rocks exhibit variation in colour, texture, and weathering intensities. The thicknesses, grain sizes and other physiographic features also vary significantly from one location to another (Figure 3). Colour varies from white to yellowish brown in profiles above quartzite around Ijapo Estate (Figure 3a), while the colour ranges from grey to light brown along Akure-Owo Expressway (Figure 3b). Profiles above porphyritic granite (Figure 3c) appear finer while those above migmatite (Figure $3 \mathrm{~d}$ ) are coarser. Textural variation in the profiles might have probably resulted from or at least influenced by differences in textures of the parent rocks. This equally may indicate the different lithologies have different susceptibilities to weathering. The degree of weathering is partly dictated by rock's mineralogy. Rocks with coarse grains are more susceptible to weathering than when the same rock has fine grains ${ }^{[30]}$.

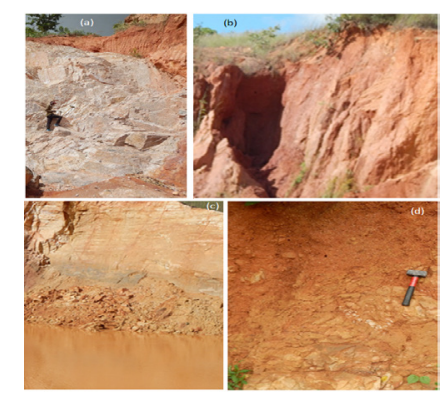

Figure 3. Colour and textural variation in profiles above crystalline basement rocks in Akure area, (a) a low-lying quartzite exposed after the thin veneer of reddish-brown soil overlying it was excavated as filling material and part of the outcrop locally sourced for building stone in Ijapo Estate area of Akure, (b) a thick grey to yellowish-brown profile overlying charnockite exposed by gully erosion along Akure-Owo Expressway, (c) yellowish-white residual soil formed from in-situ weathering of medium grained granite in the study area, (d) a reddish-brown profile above a chemically decayed in-situ migmatite in the study area .

\subsection{Geochemical Trends}

Analytical results of weathering profiles (Table 1) and the crystalline rocks underlying them (Table 2) are presented. Average analytical results in the study were compared to similar rocks in different parts of Nigeria as reference samples (P, Q, R, S and T) (Table 3). Analytical results (Table 1) show that the weathering profile is siliceous, $\mathrm{SiO}_{2}$ contents range between $61.4-62.3 \%$ in the profile above quartzite. The profile overlying charnockite, granite and migmatite has values ranging between $54.1-54.9 \%, 59.4-60.8 \%$ and $51.9-52.3 \%$ respectively. Geochemical features of the weathering profiles are significantly different from the underlying basement rocks. Average silica content of weathering profile above quartzite $(61.9 \%)$ is higher than the one above granite $(60.2 \%)$, charnockite (54.6\%) and migmatite (52.2\%). However, these average silica values are significantly lower that the values for their respective (quartzite, 91.1\%; granite, $73.8 \%$; charnockite, 58.6\%; and migmatite, 67.4\%) precursor rocks. Average alumina values in profile above migmatite $(26.3 \%)$ is higher than charnockite $(24.3 \%)$, quartzite $(23.8 \%)$, and granite $(19.9 \%)$. The discrepancies between average values of this oxide in the weathered profile and basement rocks which are respectively $13.1 \%$, $15.2 \%, 1.8 \%$ and $1.8 \%$ may have arisen due to mineralogical variation and the degree of weathering as $\mathrm{Al}_{2} \mathrm{O}_{3}$ values are higher in the weathered products. During the breakdown of rocks, feldspar and micaceous components ultimately produce aluminosilicate mineral residues that accumulate as clay minerals. There appear to be an insignificant difference between average $\mathrm{Fe}_{2} \mathrm{O}_{3}$ contents in quartzite $(1.7 \%)$ and its weathered profile $(1.94 \%)$, this may have links with monomineralic nature of the quartzite being made of metamorphosed quartz grains which does not change significantly during weathering activities. However, like the basement rock of chanockitic composition which has the highest average $\mathrm{Fe}_{2} \mathrm{O}_{3}$ value $(6.4 \%)$, the weathered profile above it equally records the highest value of $3.15 \%$. The higher average value recorded in charnockite may have resulted from ferromagnesian minerals like orthopyroxene, biotite, and iron oxide. The marginally lower average values in granite $(6.2 \%)$ and migmatite $(4.3 \%)$ may be due to lower percentage of these mineral aggregates in them. The slightly lower average values of this oxide in the weathering profile must have been attributed to chemical decomposition of ferromagnesian mineral because of their instability at near surface environments. Both basement rocks in Akure area and the weathering profiles above them contain appreciable amount of $\mathrm{Na}_{2} \mathrm{O}$ and $\mathrm{K}_{2} \mathrm{O}$. The average value of alkali $\left(\mathrm{Na}_{2} \mathrm{O}+\mathrm{K}_{2} \mathrm{O}\right)$ appears to follow a coherent pattern with migmatite recording the highest value $(5.22 \%)$ while weathered profile above migmatite equally record a maximum value $(3.48 \%)$. The average sum of alkalis in charnockite $(3.46 \%)$ and granite $(3.25 \%)$ which yielded minimally lower values produces a corresponding lower value $2.68 \%$ in profile above charnockite and $3.42 \%$ in profile above granite. Similar geochemical trends between the basement rocks and their weathering profiles (Figure 
Table 1. Analytical result of weathering profiles above the basement rocks

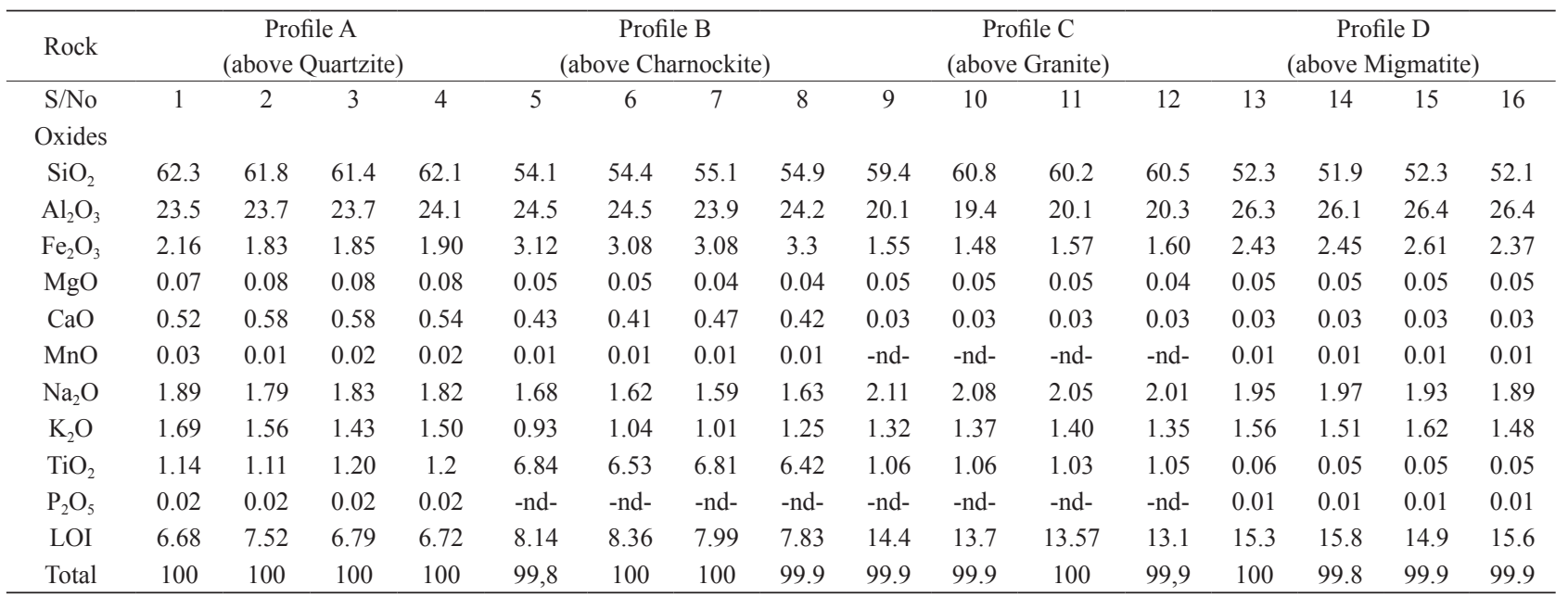

Note: -nd- (not determined).

Table 2. Chemical features of basement complex rocks in the study area

\begin{tabular}{|c|c|c|c|c|c|c|c|c|c|c|c|c|c|c|c|c|}
\hline \multirow{2}{*}{$\begin{array}{l}\text { Rock } \\
\text { S/No }\end{array}$} & \multicolumn{4}{|c|}{ Quartzite } & \multicolumn{4}{|c|}{ Charnockite } & \multicolumn{4}{|c|}{ Granite } & \multicolumn{4}{|c|}{ Migmatite } \\
\hline & 17 & 18 & 19 & 20 & 21 & 22 & 23 & 24 & 25 & 26 & 27 & 28 & 29 & 30 & 31 & 32 \\
\hline \multicolumn{17}{|l|}{ Oxides } \\
\hline $\mathrm{SiO}_{2}$ & 89.9 & 91.2 & 91.7 & 91.5 & 58.7 & 58.9 & 58.3 & 58.6 & 73.9 & 73.8 & 74.0 & 73.5 & 67.4 & 67.4 & 67.2 & 67.5 \\
\hline $\mathrm{Al}_{2} \mathrm{O}_{3}$ & 1.82 & 1.68 & 1.71 & 1.95 & 15.20 & 15.2 & 15.2 & 15.3 & 9.5 & 9.1 & 9.8 & 9.4 & 12.6 & 14.1 & 12.8 & 12.9 \\
\hline $\mathrm{Fe}_{2} \mathrm{O}_{3}$ & 1.75 & 1.68 & 1.71 & 1.65 & 6.51 & 6.35 & 6.49 & 6.37 & 6.7 & 5.3 & 6.7 & 5.9 & 4.11 & 4.62 & 4.37 & 4.25 \\
\hline $\mathrm{MgO}$ & 0.14 & 0.15 & 0.11 & 0.17 & 2.96 & 3.04 & 3.10 & 2.96 & 1.85 & 1.91 & 1.83 & 1.88 & 1.89 & 1.75 & 1.69 & 1.74 \\
\hline $\mathrm{CaO}$ & 0.11 & 0.17 & 0.14 & 0.15 & 4.37 & 4.28 & 4.34 & 4.31 & 2.11 & 2.08 & 2.16 & 2.17 & 2.51 & 2.37 & 2.14 & 1.64 \\
\hline $\mathrm{MnO}$ & 0.01 & 0.01 & 0.01 & 0.01 & 0.15 & 0.14 & 0.18 & 0.15 & 0.03 & 0.03 & 0.03 & 0.01 & 0.01 & 0.01 & 0.01 & 0.01 \\
\hline $\mathrm{Na}_{2} \mathrm{O}$ & 0.04 & 0.04 & 0.05 & 0.03 & 0.59 & 0.61 & 0.60 & 0.60 & 2.54 & 2.37 & 2.41 & 1.29 & 1.75 & 1.83 & 1.72 & 1.66 \\
\hline $\mathrm{K}_{2} \mathrm{O}$ & 0.06 & 0.08 & 0.04 & 0.06 & 2.91 & 2.87 & 2.83 & 2.85 & 1.16 & 1.04 & 1.07 & 1.11 & 3.61 & 3.57 & 3.49 & 3.25 \\
\hline $\mathrm{TiO}_{2}$ & 0.03 & 0.03 & 0.04 & 0.03 & 0.81 & 0.79 & 0.80 & 0.74 & 0.1 & 2.8 & 1.0 & 2.8 & 0.69 & 0.75 & 0.48 & 0.62 \\
\hline $\mathrm{P}_{2} \mathrm{O}_{5}$ & 0.02 & 0.02 & 0.04 & 0.01 & 0.01 & 0.01 & 0.01 & 0.01 & -nd- & -nd- & -nd- & -nd- & -nd- & -nd- & -nd- & -nd- \\
\hline LOI & 6.12 & 4.94 & 4.45 & 4.44 & 7.79 & 7.81 & 8.15 & 8.11 & 2.14 & 1.58 & 2.0 & 1.94 & 5.4 & 3.6 & 6.1 & 6.43 \\
\hline Total & 100 & 100 & 100 & 100 & 100 & 100 & 100 & 100 & 100 & 100 & 100 & 100 & 99.9 & 100 & 100 & 100 \\
\hline
\end{tabular}

Note: -nd- (not detected).

Table 3. Comparison of average chemical composition of the profile with similar rocks

\begin{tabular}{cccccccccc}
\hline Oxides & $\begin{array}{c}\text { Profile } \mathrm{A} \\
\text { Quartzite }\end{array}$ & $\begin{array}{c}\text { Profile B } \\
\text { Charnockite }\end{array}$ & Profile C Granite & $\begin{array}{c}\text { Profile D } \\
\text { Migmatite }\end{array}$ & $(\mathrm{P})$ & $(\mathrm{Q})$ & $(\mathrm{R})$ & $(\mathrm{S})$ & $(\mathrm{T})$ \\
\hline $\mathrm{SiO}_{2}$ & 61.9 & 54.6 & 60.2 & 52.2 & 56.9 & 47.9 & 38.67 & 59.97 & 64.45 \\
$\mathrm{Al}_{2} \mathrm{O}_{3}$ & 23.8 & 24.3 & 19.9 & 26.3 & 27.2 & 33.07 & 9.45 & 24.66 & 20.28 \\
$\mathrm{Fe}_{2} \mathrm{O}_{3}$ & 1.94 & 3.15 & 1.55 & 2.47 & 1.90 & 3.15 & 2.7 & 3.32 & 0.63 \\
$\mathrm{MgO}$ & 0.08 & 0.05 & 0.05 & 0.05 & - & 0.19 & 8.5 & 0.27 & 0.12 \\
$\mathrm{CaO}$ & 0.55 & 0.43 & 0.03 & 0.03 & 0.63 & 0.58 & 15.84 & 0.46 & 0.28 \\
$\mathrm{MnO}$ & 0.02 & 0.01 & $-n d-$ & 0.01 & trace & trace & - & 0.01 & 0.01 \\
$\mathrm{Na} 2$ & 1.83 & 1.63 & 2.06 & 1.94 & 1.59 & 1.19 & 2.76 & 1.78 & 0.18 \\
$\mathrm{~K}_{2} \mathrm{O}$ & 1.55 & 1.06 & 1.36 & 1.54 & 1.72 & 1.17 & 2.76 & 0.48 & 0.42 \\
$\mathrm{TiO}_{2}$ & 1.16 & 6.65 & 1.05 & 0.05 & 1.12 & 1.25 & - & 20.2 & 0.84 \\
$\mathrm{P}_{2} \mathrm{O}_{5}$ & 0.02 & - nd- & - nd- & 0.01 & 0.03 & 0.03 & - & - & - \\
$\mathrm{LOI}$ & 6.9 & 8.08 & 13.69 & 15.4 & 6.56 & 8.00 & - & 16.14 & - \\
\hline
\end{tabular}

Note: -nd- (not detected); trace (below detection limits)

P: Greyish clay ${ }^{[32]}$; Q: Reddish brown clay ${ }^{[32]}$; R: Industrial clays and rocks ${ }^{[33]}$; S: Kaoline deposits, Ubulu-Uku, Awo-Omama and Buan, Southern Nigeria; ${ }^{[34]}$; T: Iyuku clay ${ }^{[35]}$. 
4) indicate coherent relationship exists between them. The correlation of values may imply copious evidence that the composition of weathered products of these rocks significantly depend on the parent rock. Analytical result (Table 1 and Table 2) reveals that the loss of ignition (LOI) values is high. However, LOI values are higher in the weathering profiles when compared to their crystalline rock equivalent. The difference may be due to higher porosity or ability of the weathering residues to absorb water into their crystal structures which is ultimately given off during decomposition of the soil during analysis as loss on ignition. Except for higher $\mathrm{SiO}_{2}$ values, the chemical composition of Akure weathering profile resembles that of clay and lateritic soils. Even though the physico-mechanical parameters of these overlying soil profiles are not evaluated in this study; however, field examination reveals they are of low plasticity and can barely be moulded into balls when water was added implying, they tend towards kaolinitic clay. Previous research reveals that clays in the basement complex areas of Nigeria could exhibit variable geochemical features or differ markedly in their industrial application. Average silica content of weathering profile above quartzite $(61.9 \%)$ in Akure is marginally lower than Iyuku clay ${ }^{[35]}$ (Table 3). However, silica content of weathering profile above granite $(60.2 \%)$ in Akure area is comparable to Kaoline deposits reported by ${ }^{[34]}$ from Ubulu-Uku, Awo-Omama and Buan areas of Southern Nigeria. Average alumina content of reddish-brown clay (33.07\%) ${ }^{[32]}$ is significantly higher than all the investigated soil profiles in Akure. However, the average content of this oxide in profile above charnockite $(24.3 \%)$ is comparable to kaoline deposits $(24.66 \%)$ from southern Nigeria ${ }^{[34]}$. This average is equally higher than clay $(9.45 \%)$ evaluated by ${ }^{[33]}$ and Iyuku clay ${ }^{[35]}$. Average $\mathrm{Fe}_{2} \mathrm{O}_{3}$ content in profile above charnockite (3.15\%) in Akure area is comparable to the reddish-brown clay ${ }^{[32]}$ while the average iron content in profile above quartzite in the study area (1.94\%) is comparable to grey clay $(1.90 \%){ }^{[32]}$. All the weathering profiles evaluated from the study contain $\mathrm{CaO}$ contents that are grossly lower than (15.84\%) recorded for industrial clays ${ }^{[33]}$. Average $\mathrm{TiO}_{2}$ contents of weathering profiles in the study area are grossly lower than Kaoline deposits from Ubulu-Uku, Awo-Omama and Buan, area of southern Nigeria ${ }^{[34]}$. This research indicates that weathering residues across many domains of Nigeria basement are compositionally variable.

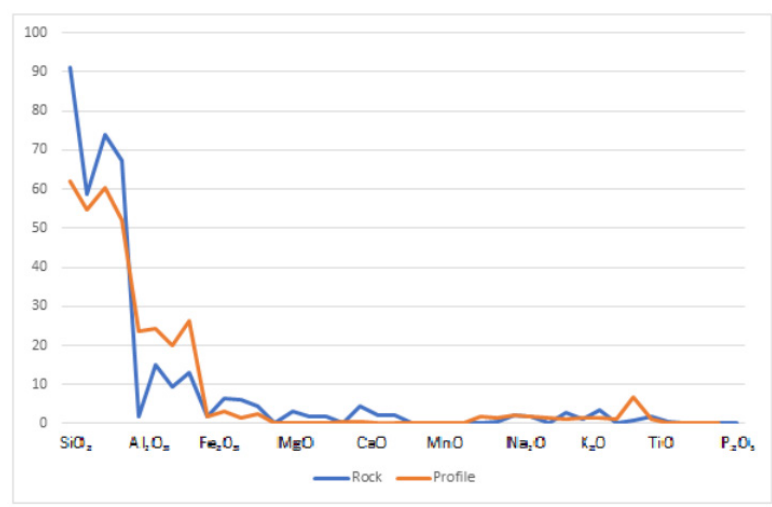

Figure 4. Correlation of chemical composition of the basement rocks and the weathering profiles.

\section{Conclusions}

From the study, the following conclusions are made. The weathering profiles are formed in-situ and vary in colour, texture, and thickness. The composition is siliceous and there exist some correlations between the chemistries of weathering profile and their underlying crystalline basement rocks. The geochemical features of the profiles portray high alumina and alkali contents but with slight variations that are related to the parent rock chemistry. Field investigation shows the weathering profiles have characteristic features comparable to kaolinitic and low plastic clays and are like other industrial clay deposits in southern Nigeria.

\section{Acknowledgements}

The authors wish to acknowledge with thanks a Research Fellow in person of Dr. Seidu Akun Abdallah of the Department of Chemistry, University of Malaya for facilitating the geochemical analysis. Students who assisted on logistics during fieldwork are equally appreciated.

\section{References}

[1] Oyawoye, M.O. (1964). The Geology of the Nigerian Basement complex. Journal of Mining and Geology, 1, 87-102.

[2] Odeyemi, I.B. (1981). A review of the orogenic events in the Precambrian basement of Nigeria, West Africa. Geologische Rundschau, 70(3), 897-909.

[3] Ajibade, A.C., Woakes, M. and Rahaman, M.A. (1987). Proterozoic crustal development in the Pan-African Regime of Nigeria. In: Kroner, A. (Ed.), Proterozoic Lithospheric Evolution AGU, Washington DC.

[4] Rahaman, M.A (1988). Recent advances in the study of the basement complex of Nigeria. In: Precambrian Geology of Nigeria (Oluyide, P.O; Mbonu, W.C; 
Ogezi, A.E; Egbuniwe, I.G; Ajibade, A.C and Umeji, A.C. (Eds.), a publication of Geological survey of Nigeria.

[5] Elueze, A.A. (1986). Petrology and Gold mineralization of the Amphibolite belt. Ilesha area Southwestern Nigeria. Geologic on Mijnbouw, 65, 189-195.

[6] Ekwueme, B.N. (1990). Rb-Sr ages and petrologic features of Precambrian rocks from the Oban Massif, southeastern Nigeria. Precambrian Research, 47(3-4), 271-286.

[7] Dada, S.S. (2006). Proterozoic Evolution of Nigeria. In: Oshin, O. (ed.) The Basement Complex of Nigeria and its Mineral Resources. Petrochemical Services Ltd. Ibadan, Nigeria. 29 - 45.

[8] Okonkwo, C.T. and Folorunso, I.O. (2013). Petrochemistry and geotectonic setting of granitic rocks in Aderan Area, SW Nigeria. Journal of Geography and Geology, 5(1), 30.

[9] Hurley, P.M., Fairbairn, H.W. and Pirson, W.H. (1966). Continental drift investigations. Massachussets. Institute of Technology, U.S.A. $14^{\text {th }}$ Annual Progress Report., 1381-14, UASEC, 3-15.

[10] Hubbard, F.H. (1975). Precambrian crustal development in western Nigeria: Indications from the Iwo region. Geological Society of America, Bulletin, 86, 548-554.

[11] Dada, S.S., Lancelot, J.R. and Briqueu, L. (1989). Age and origin of the annular charnockitic complex at Toro, Northern Nigeria: U-pb and Rb-Sr evidence, Jour. African Earth Sciences, 9:227-234.

[12] Ekwueme, B.N., and Kröner, A. (2006). Single zircon ages of migmatitic gneisses and granulites in the Obudu Plateau: Timing of granulite-facies metamorphism in southeastern Nigeria. Journal of African Earth Sciences, 44(4-5), 459-469.

[13] Okonkwo, C.T. and Ganev, V.Y. (2012). U-Pb Geochronology of the Jebba granitic gneiss and its implications for the paleoproterozoic evolution of Jebba area, southwestern Nigeria. International Journal of Geosciences, 3, 1065-1073. http://dx.doi. org/10.4236/ijg.2012.35107

[14] Fitches, W.R., Ajibade, A.C., Egbuniwe, I.G., Holt, R.W. and Wright, J.B, (1985). Late Proterozoic schist belts and plutonism in NW Nigeria. Journal of Geological Society London, 142, 319- 337.

[15] Elueze, A.A. (1992). Rift system for Proterozoic schist belts in Nigeria. Tectonophysics, 209, 167-169

[16] Caby, R. and Boesse, J.M. (2001). Pan-African nappe system in southwest Nigeria: the Ife-Ilesha schist belt. Journal African Earth Sciences, 33, 21-30.

[17] Danbatta, U.A. (2003). The litho-geochemical frame- work underlying the geotectonic evolution of the Kazaure Schist Belt, NW Nigeria. The Nigerian Journal of Scientific Research, 4(1), pp. 1-13.

[18] Akande, S.O., Fakorede, O. and Mucke, A. (1988). Geology and genesis of gold-bearing quartz veins at Bin Yauri and Okolom in the Pan-African domain of western Nigeria. Geologie en Mijnbouw, 67(1), 4151.

[19] Oyinloye, A.O. (1992). Genesis of the Iperindo gold deposit, Ilesha schist belt, southwestern Nigeria. $\mathrm{Ph}$. D Thesis, University of Wales, UK.

[20] Adekoya, J.A. and Oladeji, B.O. (1985). "Geological and Structural Setting of the Muro Hills Banded Iron-Formation, Plateau State, Nigeria," Journal of Mining and Geology, 22, 161-185.

[21] Muotoh, E.O.G., Oluyide, P.O., Okoro, A.U. and Muogbo, O. (1988). The Muro Hills Banded Iron-Formation. Precambrian Geology of Nigeria (A publication of the Geological Survey), 219.

[22] Adekoya, J.A. (1991). "The Geology of Banded Iron-Formations in the Precambrian Basement Complex of Northern Nigeria," Ph. D. Dissertation, University of Ibadan, Ibadan.

[23] Adekoya, J.A., Okonkwo, C.T. and Adepoju, M.O. (2012). Geochemistry of Muro Banded Iron-Formation, Central Nigeria, International Journal of Geosciences, 3, 1074-1083

[24] Okunlola, O.A., and Akinola, O.O. (2010). Petrochemical characteristics of the Precambrian rare metal pegmatite of Oke-Asa area, Southwestern Nigeria: Implication for Ta-Nb Mineralization. RMZ-Materials and Geo Environment, 57, 525-538.

[25] Elueze, A.A. and Bolarinwa, A.T. (1995). Assessment of functional application of lateritic clay bodies in Ekiti environs, Southwestern Nigeria. Journal of Mining and Geology, 31(1), 79-87.

[26] Elueze, A.A., and Bolarinwa, A.T. (2001). Appraisal of the residual and sedimentary clays in parts of Abeokuta Area, Southwestern Nigeria. Journal of Mining and Geology, 37(1), 7-14.

[27] Akinyemi, S.A., Ogunniyi, S.O., Ojo, A.O., Gitari, W.M., Momoh, A., Akinola, O.O., Talabi, A.O., Afolagboye, L.O., Olaolorun, O.A. and Ayodele, O.S. (2014). Mineralogy, Physicochemical Characteristics and Industrial Potential of Some Residual Clay Deposits within Ekiti State, Southwestern Nigeria. Journal of Environment and Earth Science, 4(17).

[28] Lindqvist J.E.A., Kesson, U. and Malaga, K. (2007). Microstructure and functional properties of rock materials. Mater Character, 58(11-12):1183-1188.

[29] Arif M., Bukhari, S.W.H., Muhammad, N. and Sa- 
jid, M. (2013). petrography and physico-mechanical properties of rocks from the Ambela granitic complex, NW Pakistan. Sciences World Journal, 1-8.

[30] Afolagboye, L.O., Talabi, A.O. and Akinola, O.O. (2015). "Evaluation of selected basement complex rocks from Ado-Ekiti, SW Nigeria, as source of road construction aggregates" Bulletin of Engineering Geology and Environment, 75(2) 853-865.

[31] GSN (1974). Geological Survey of Nigeria, Geological Map of Nigeria 1:2,000,000; Published by Geological Survey of Nigeria (GSN) Geological Survey Sheet 51, Akure, SW Nigeria.

[32] Obaje, S.O., Omada, J.I., and Dambatta, U.A. (2013). Clays and their industrial applications: Synoptic Review, International Journal of Science and Technolo- gy, 3(5), 264-270.

[33] Murray, H.H. (1960). Clay industrial materials and rocks, 3rd Ed., Publication of American Institute of Mining, Metallurgy and Petroleum Engineering, New York, Seeley, W. Mudd Series, 259-284.

[34] Emofurieta, W.O., Kayode, A.A. and Coker, S.A. (1992). Mineralogy, geochemistry, and economic evaluation of the kaolin deposits near Ubulu-Uku, Awo-Omama and Buan in Southern Nigeria, Journal of Mining and Geology, 28, 211-220.

[35] Onyeobi, T.U.S., Imeokparia, E.G.O., Ilegieuno, A. and Egbuniwe, I.G. (2013). Compositional, Geotechnical and Industrial Characteristics of Some Clay Bodies in Southern Nigeria. Journal of Geography and Geology, 5(2), 73-84. 